NS5179-4504

Fire Research Publications. 1977

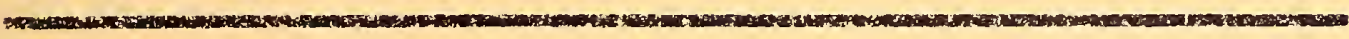

Mora josor.

Coneer for Fire Research

National Enginearin'y Laboratory

Net:onal Bureat of Standards

Weshington, 0.モ. 20234

Suly :979

Final Soport

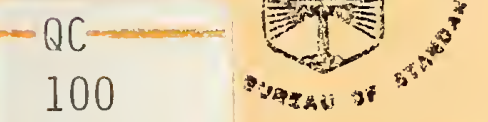

-U56

1978

TOWAL MAEAU OF STAMEATOS

C. 2 



\section{FIRE RESEARCH PUBLICATIONS,}

\section{7}

Nora H. Jason

Center for Fire Research

National Engineering Laboratory

National Bureau of Standards

Washington, D.C. 20234

July 1978

Final Report

U.S. DEPARTMENT OF COMMERCE, Juanita M. Kreps, Secretary

Dr. Sidney Harman, Under Secretary

Jordan J. Baruch, Assistant Secretary for Science and Technology

NATIONAL BUREAU OF STANDARDS, Ernest Ambler, Director 
"Fire Research Publications, 1977 " is a supplement to the previous editions:

$\begin{array}{lllll}1969-72 & \text { NBSIR 73-246 } & \text { NTIS Order No. COM-74-10989 } & \$ 3.25 \\ 1973 & \text { NBSIR 74-511 } & \text { COM-74-11448 } & \$ 3.25 \\ 1974 & \text { NBSIR 75-736 } & \text { COM-75-11018 } & \$ 3.25 \\ 1975 & \text { NBSIR 76-1120 } & \text { PB }-257837 & \$ 3.50 \\ 1976 & \text { NBSIR 77-1277 } & \text { PB }-269965 & \$ 3.50\end{array}$

Only publications prepared by members of the Center for Fire Research (CFR), by orher National Bureau of Standards (NBS) personnel or external laboratories under contract or grant from the CFR ara cited. Articles published in NBS house organs also are cited.

For documents that are avallable for purchase from either the Government Printing Office (GPO) or the National Technscal Information Service (NTIS), the specific order number and paper copy price (prices are subject to change) have been included in the cication.

GPO documents are obtained by writing directiy to the Superintendent of Documents, U.S. Govermment Printing Office, Washington, D.C. 20402. Indicate the SD Catalog No. for each document requested. Orders must be prepaid. Remittance should be made by check or money order payable to the "Superintendent of Documents, U.S. Government Printing Office."

NTIS documents are obtained by writing directly to the National Technical Information Service, U.S. Department of Comerce, Springfield, Virginia 22161. Indicate the NTIS Order No. for each document requested. Microfiche coples of the documents also are available at a cost of $\$ 3.00$ for domestic orders. All prices are subject to change. Orders must be prepared by check or money order payable to "National Technical Information Service" or by utilizing an NTIS form with your deposit account number. 


\section{CONTENTS}

Page

I. Journal Articles and Conference Proceedings

II. National Bureau of Standards Publications

A. National Bureau of Standards Dimensions 2

B. National Bureau of Standards Interagency 2 Reports

C. National Bureau of Standards Technical Notes 4

III. Contract and Grant Reports 4

IV. Author Index $\quad 8$ 


\section{Journal Articles and Conference Proceedings}

Baum, H.R. Laminar Flow Induced by a Point Source of Heat. Journal of Research of the Natinal Bureau of Standards - B. Mathematical Sclence, Vol. 81B, Nos. 1 and 2, 45-60, January-June 1977.

Bright, R.G. NBS Answers FEMA's Criticisms of the Indiana Dunes Tests of Residential Smoke Detectors. Fire Journal, Vol. 71, No. 5, 47-49, 99, September 1977.

Gross, D. Measurements of Fire Loads and Calculations of Fire Severity. Wood \& Fiber, Vol. 9, No. 1, Special Fire Symposium Issue, Part 1, Spring 1977.

King, D.S., Schenck, P.K., Smyth, K.C. and Travis, J.C. Direct Calibration of Laser Wavelength and Bandwidth Using the Optogalvanic Effect in Hollow Cathode Lamps. Applied Optics, Vo1. 16, 2617-2619, October 1977.

Krasny, J.F. and Peacock, R.D. Coments on Flanmability Assessment of apparel Fabrics. Textile Chemist and Colorist, Vol. 9, No. 4, 32-33, April 1977.

McCaffrey, B.J. and Heskestad, G. A Robust Bidirectional Low-Velocity Probe for Flame and Fire Application. Combustion and Flame, Vo1. 26, No. 1, 125-127, February 1976.

McCaffrey, B.J. anc Rockett, J.A. Static Pressure Measurements of Enclosure Fires. Journal of Research of the National Bureau of Standards, Vol. 82, No. 2, 107-117, September-October 1977.

McCarter, R.J. Smoldering Combustion of Cotton and Rayon. In: Proceedings of the 1977 Symposium on Textile Flammability, LeBlanc Research Corporation, New Orleans, Apri1 20-21, 1977. Journal of Consumer Product Flamability, Vol. 4, 346-358, December 1977.

Miles, L.B. The Burning Behavior of Borderline Fabrics. In: Proceedings of the 1977 Symposium on Textile Flammability, LeBlanc Research Corporation, New Orleans, April 20-21, 1977.

Mulholland, G.W., Lee, T.G. and Baum, H.R. The Coagulation of Aerosols with Broad Initial Size Distributions. Journal of Collold and Interface Science, Vo1. 62, No. 3, 406-420, December 1977.

Quintiere, J., McCaffrey, B.J. and Kashiwagi, T. A Scaling Study of a Corridor Subject to a Room Fire. Presented at the Heat Transfer Division of the American Society of Mechanical Engineers, ASME Paper No. 77-HT-72, Salt Lake City, Utah, August $15-17,1977$. 
Schenck, P.K., King, D.S., Smyth, K.C., Travis, J.C. and Turk, G.C. New Analytical and Spectroscopic Tool - The Opto-Galvanic Effect. International Conference on Lasers in Chemistry, Proc., Pp. 431-435, London, May 29-June 2, 1977.

Slater, J.A. Data Systems and Fire Casualty Information. In: Fire Casualties, Proceedings of the First Conference and Workshop, Applied Physics Laboratory, Johns Hopkins University, Maryland, May 28-29, 1975.

II. National Bureau of Standards Publications

\section{A. National Bureau of Standards Dimensions}

Fire Research with the Gypsum Industry. NBS Dimensions, Vol. 61, No. 1, 20, January 1977. GPO C13.13/January/1977;

$\$ 1.05$.

Lyons, J. Fire Research. NBS Dimensions, Vol. 61, No. 3, 2, March 1977. GPO, order as C13.13/March/1977; \$1.05.

B. National Bureau of Standards Interagency Reports

NBSIR 77-1209 Benjamin, I.A., Fung, F. and Roth, I. Control of Smoke Movement in Buildings: A Review. July 1977. Final Report. NTIS Order No. PB-269866; $\$ 4.00$.

BBSIK 77-1222 Lee, T.G. Reproducibility of the Radiant Panel Test Method (ASTM E 162-67) Using Polyurethane Foam, Neoprene and Hardboard Specimens. March 1977. Final Report. NTIS Order No. PB-265089; $\$ 4.00$.

NBSIR 77-1225 Fung, F.C.W. and Zile, R.H. Test and Evaluation of the Smoke Control Capabilities of the San Diego Veterans Administration Hospital. April 1977. Einal Report. NTIS Order No. PB-270856; $\$ 8.00$.

NBSIR 77-1234 Birky, M.M. Hazard Characteristics of Combustion Products in Fires: The State-of-the-Art Review. May 1977. Final Report. NTIS Order No. PB-267828; $\$ 4.00$.

NBSIR 77-1236 Zawistowski, E.A., Krasny, J.F., Braun, E., Peacock, R. and Willams, N. The Measurement of Fabric Flammability Parameters in Experiments Simulating Human Movement in Burn Accldents. June 1977. Final Report. NTIS Order No. PB-268902; $\$ 4.00$.

NBSIR 77-1251 Calvano, N.J. Considerations in Estabifshing Performance Criteria for Structural Firefighters ${ }^{7}$ Helmets. May 1977. NTIS Order No. PB-269531; \$5.50. 
NBSIR 77-1260 Fung, F.C.W. A Computer Program for the Thermal Analysis of the Fire Endurance of Construction Walls. May 1977. Final Report. NTIS Order No. PB-268112; $\$ 4.50$.

NBSIR 77-1264 Jason, N.H. Fire Research Specialists: A Directory. July 1977. NTIS Order No. PB-272475; $\$ 7.25$.

NBSIR 77-1265 Lawson, J.R. An Evaluation of Fire Properties of Generic Gypsum Board Products. August 1977. Final Report. NTIS Order No. PB-271097; \$4.50.

NBSIR 77-1273 Nelson, H.D. Directions to Improve Application of Systems Approach to Fire Protection Requirements for Buildings. September 1975-December 1976. July 1977. Interim Report. NTIS Order No. PB-276004; \$4.50.

NBSIR 77-1277 Jason, N.H. Fire Publication, 1976. July 1977. Final Report. NTIS Order No. PB-269965; $\$ 3.50$.

NBSIR 77-1282 Hayes, Jr., W.D. and Custer, R.I.E. Investigation of the Sultability of Light Duty Pipe Hangers for Use in Residential and Care Type Sprinkier Systems. Ocrober 1977. Final Report. NTIS Order No. PZ-273575; \$4.50.

NBSIR 77-1287 iiu, S.T. Analyzical and Experimental Study of Evaporative Cooling and Room Fire Suppression by Corridor Sprinkler System. October 1977. Final Report. NTIS Order No. PB-273576; $\$ 5.25$.

NBSIR 77-1290 Babrauskas, V. Combustion of Mattresses Exposed to Flaming Ignition Sources. Part 1: Full-Scale Tests and Hazard Analysis. September 1977. Final Report. NTIS Order No. PB-272064; $\$ 7.25$.

NBSIR 77-1295 Breese, J.N. Tests on Insulative Bartiers as a Method of Protecting Neoprene Core Mattresses. November 1977. Final Report. NTIS Order No. PB-275170; $\$ 4.50$.

NBSIR 77-1302 Evans, D.D., Breden, L.H. A Numerical Technique to Correct heat Release Rate Calorimetry Data For Apparatus Time Delay. November 1977. Final Report. NTIS Order No. PB-275173; $\$ 4.50$.

NBSIR 77-1308 Huggett, C. Annual Conference on Fire Research. October 1977. Final Report. NTIS Order No. PB-273589; $\$ 9.00$.

NBSIR 77-1312 Lee, T.G.K. and Mulholland, G. Physical Propertles of Smokes Pertinent to Smoke Detector Technology. November 1977. Final Report. NTIS Order No. PB-274330; $\$ 4.50$. 
NBSIR 77-1313 Stahl, F.I. and Archea, J. An Assessment of the Technical Literature on Egress from Buildings. October 1977. Final Report. NTIS Order No. PB-273944; \$5.25.

NBSIR 77-1318 Quintiere, J., McCaffrey, B., Kashiwagi, T., Den Braven, K., et a1. The Impact of a Room Fire on a Corridor with Considerations of Fuel Load, Ventilation and Scaling. November 1977. Final Report. NTIS Order No. $\mathrm{PB}-273942 ; \$ 5.25$.

NBSIR 77-1381 Buchbinder, B., Helzer, S.G., and Offensend, F.L. Preliminary Report on Evaluating Alternatives for Reducing Upholstered Furniture Fire Losses. November 1977. Preliminary Report. NTIS Order No. PB-273943; $\$ 4.50$.

C. National Bureau of Standards Technical Notes

NBS IN 945 Parker, W.J. An Investigation of the Fire Environment in the ASTM E84 Tunnel Test. August 1977. GPO. SD Catalog No. C13.10:46:945; $\$ 2.20$.

\section{Contracts and Grants}

FAA-RD-77-47 Manka, M.J., Pierce, H. and Huggett, C. Studies of the Flash Fire Potential of Afrcraft Cabin Interior

Materials. December 1977. Final Report. NTIS Order No. $A D-A 048475 / 8 S T ; \$ 4.50$.

NBS-GCR-77-82 Harpe, S.W., Waterman, T.E., and Christian, W.J. Detector Sensitivity and Sitirg Requirements for Dwellings - Phase 2. July 1976. Final Report. NBS Contract No. 4-36092. NTIS Order No. PB-263882; $\$ 10.00$.

NBS-GCR-77-83 Ho, C.Y., Desai, P.D., Wu, K.Y., Havill, I.N and Lee, T.Y. Thermophysical Properties of Polystyrene and Poly (Vinyl Chloride). March 1977. Final Report. NBS Contract 510374. NTIS Order No. PB-265228; \$5.50.

NBS-GCR-77-84 Yang, K.T. and Chang, L.C. UNDSAFE-1; A Computer Coce for Buoyant Flow in an Enclosure. March 1, 1977. TR-79002-71-1. NBS Grant G7-9002. NTIS Order No. $\mathrm{PB}-267287 ; \$ 5.50$.

NBS-GCR-77-85 Alarie, Y. and Barrow, S.C. Toxicity of Plastic Combustion Products. Toxicological Methodologies to Assess the Relative Hazards of Thermal Decomposition Products from Polymeric Materials. February 1976/1977. NBS Grant No. 5-9005. NTIS Order No. PB-267233; \$9.75. 
NBS-GCR-77-86 Heskestad, G. and Delichatsios, M.A. Environments of Fire Detectors - Phase 1: Effect of Fire Size, Celling Height and Materials. Volume 1. Measurements. FMRC Serial No. 22427. May 1977. NBS Grant No. 6-9001. NTIS Order No. PB-272882; $\$ 9.25$.

NBS-GCR-77-90 Splvak, S.M., Block, I., Smith, B.F., Yeh, K., Bhat, G.R., Sun, R.L., Miles, L., Fairall, P. and Potthoff, P. Extinguishability as a Component Measure of Flamability Hazard. April 1977. NBS Grant 4-9010. NTIS Order No. PB-269487; $\$ 7.50$.

NBS-GCR-77-92 Stahl, F.I. Simulating Human Behavior in High-Rise Building Fires: Modeling Occupant Movement Through a Fire Floor from Initial Alert to Safe Egress. June 26, 1975/August 1977. NTIS Order No. PB-273166; $\$ 5.25$.

NBS-GCR-77-93 Lerup, L., Cronrath, D. and Liu, J.K.C. Human Behavior in Institutional Fires and Its Design Implication. February 28, 1977. Final Report. MBS Grant No. 6-9013. NTIS Order No. PB-271980; $\$ 9.00$.

NBS-GCR-77-94 Bryan, J.L. Smoke as a Determinant of Human Behavior in Fire Situations (Project People). June 30, 1977. Final Report. NBS Grant No. 4-9027. NTIS Order No. PB-271755; \$11.75.

NBS-GCR-77-95 Heskestad, G. and Dellchatsios, M.A. Environments of Fire Detectors - Phase 1: Effect of Fire Size, Ceiling Height and Materials. Vol. 2. Analysis. July 1977. FMRC Serial No. 22427. NTIS Order No. PB-272883; $\$ 7.25$.

NBS-GCR-77-96 Hopkins, D.I. Fabric and Dye Variations as Flammability Determinants: An Application of the Mushroom Apparel Flamability Tester. August 1977. Finai Report. NBS Grant No. 4-9019. NTIS Order No. PB-280993; \$6.50.

NBS-GCR-77-97 Veldman, C.C., Kubota, T. and Zukoski, E.E. An Experimental Investigation of the Heat Transfer from a Buoyant Gas Plume to a Horizontal Ceiling - Part l: Unobstructed Celling. March - June 1, 1975. Quarterly Progress Report. NBS Grant No. 5-9004. NTIS Order No. PB-272059; $\$ 6.50$. 
NBS-GCR-77-98 Zukoski, E.E. and Kubota, T. An Experimental

Investigation of the Heat Transfer from a Buoyant Gas Plume to a Horizontal Ceiling - Part 2: Effects of Ceiling Layer. June-September 1, 1975. Quarterly Progress Report. NBS Grant No. 5-9004. NTIS Order No. PB-280746; $\$ 6.00$.

NBS-GCR-77-99 Durbetaki, P., Tincher, W.C., Lloyd, L.R., Lowerly, R.P., Tingle, W.J. and Wolfe, Jr., V.L. Prediction of Fire Hazard from Fabrics and Bullding Materials. February 28, 1977. Fifth Research Report. NBS Grant No. AEN72-03359 A04. NTIS Order No. PB-273977; \$10.75.

NBS-GCR-77-102 Keating, J.P. and Loftus, E.F. Vocal Emergency Alarms in Hospitals and Nursing Facilities: Practice and Potential. July 1977. Final Report. NBS Grant No. 6-9015. NTIS Order No. PB-273165; \$4.50.

NBS-GCR-77-103 Watts, J. Goal Orlented Systems Approach. July 12, 1977. NBS Grant No. 7-9007. NTIS Order No. PB-273174; $\$ 6.50$.

NBS-GCR-77-105 Beyler, C.L. Effect of Selected Variables on the Distribution of Water from Automatic Sprinklers. June 1977. NBS Grant No. 4-36092. NTIS Order No. PB-275083, $\$ 5.25$.

NBS-GCR-77-106 Lerup, L. People in Fires: A Manual for Mapping. 1977. NBS Grant No. 5-9016. NTIS Order No. PB-275155; \$4.50.

NBS-GCR-77-108 Waterman, T. Fire Development in a Room - A Bibliography. August 1976. NBS Grant No. 5-9018. NTIS Order No. $\mathrm{PB}-278634 ; \$ 11.00$.

NBS-GCR-77-110 Waterman T.E. and Pape, R. A Study of the Development of Room Fires. September 1976. NBS Grant No. 5-9018. NTIS Order No. PB-278648; $\$ 6.00$.

NBS-GCR-77-111 Pape, R., Mavec, J., Kalkbrenner, D. and Waterman, T. Semistochastic Approach to Pradicting the Development of a Fire in a Room from Ignition to Flashover. Program Documentation and Users GuIde. June 1976. NBS Grant No. 5-9018. NTIS Order No. PB-278643; \$6.00.

NBS-GCR-77-112 Pape, R. and Waterman, T. Semistochastic Approach to Predicting the Development of a Fire in a Room from Ignition to Flashover. Program Documentation and Users Guide (Addendum). August 1976. NBS Grant No. 5-9018. NTIS Order No. 278644; $\$ 4.00$. 
NBS-GCR-77-113 Pape, R. and Waterman, T. Modifications to the RFires Preflashover Room F1re Computer Model. March 1977.

NBS Grant No. T-9022. NTIS Order No. PB-278820; $\$ 6.50$. 
A.

Alarie, Y., 4

Archea, J., 4

B

Babrauskas, V., 3

Barrow, S.C., 4

Baum, H.R., I

Benjamin, I.A., 2

Beyler, C.I., 6

Bhat, G.R., 5

Birky, M.M., 2

Block, I., 5

Braun, E., 2

Breden, L.H., 3

Breese, J.N., 3

Bright, R.G., 1

Bryan, J.L., 5

Buchbinder, B., 4

C

Calvano, N.J., 2

Chang, L.C., 4

Christian, W.J., 4

Cronrath, D., 5

Custer, R.L.P., 3

D

Delichatsios, M.A., 5

Den Braven, K., 4

Desai, P.D., 4

Durbetaki, P., 6

E

Evans, D.D., 3

F

Fairall, P., 5

Fung, F., 2, 3
G

Gross, D., I

$\mathrm{H}$

Harpe, S.W., 4

Havi11, T.N., 4

Hayes, Jr., W.D., 3

Helzer, S.G., 4

Heskestad, G., 1, 5

Ho, C.Y., 4

Hopkins, D.L., 5

Huggett, C., 3, 4

J

Jason, N.H., 3

K

Kalkbrenner, D., 6

Kashiwag1, T., 1, 2

Keating, J.P., 6

King, D.S., 1, 2

Krasny, J.F., 1, 2

Kubota, T., 5, 6

L

Lawson, J.R., 3

Lee, T.G., $1,2,3$

Lee, T.Y., 4

Lerup, L., 5, 6

Liu, J.K.C., 5

L1U, S.T., 3

Lloyd, L.R., 6

Loftus, E.F., 6

Lowerly, R.P., 6

Lyons, J., 2 
Manka, M.J., 4

Mavec, J., 6

McCaffrey, B.J., 1, 4

McCarter, R.J., 1

Miles, L.B., 1, 5

Mulholland, G.W., 1, 3

$\mathrm{N}$

Nelson, H.E., 3

\section{P}

Pape, R., 6, 7

Parker, W.J., 4

Peacock, R.D., 1, 2

Pierce, H., 4

Potthoff, P., 5

0

Offensend, F.L., 4

Q

Quintiere, J., 1, 4

R

Rockett, J.A., 1

Roth, L., 2

S

Schenck, P.K., 1, 2

Slater, J.A., 2

Smith, B.F., 5

Smyth, K.C., 1, 2

Spivak, S.M., 5

Stah1, F.I., 4, 5
Tincher, W.C., 6

Tingle, W.J., 6

Travis, J.C., 1, 2

Turk, G.C., 2

V

Veldman, C.C., 5

W

Waterman, T.E., 4, 6, 7

Watts, J., 6

Williams, N., 2

Wolfe, Jr., V.I., 6

Wu, K.Y., 4

$\mathrm{Y}$

Yang, K.T., 4

Yeh, K., 5

Z

Zawlstowski, E.A., 2

Zile, R.H., 2

Zukoski, E.E., 5, 6 
NOD-114A IREV. $\mid 1.77)$

U.S. OEPT. OF COMM BIBLIOGRAPHIC DATA SinEET 1. PUBLICATION OR REPORT NO. NBSIR 78-1504

2. Gor't Accession

3. Recipient's Accession No. 4. TITLE AND SUBTITLE

Fire Research Publications, 1977

5. Publication Date July 1978

6. Performing Organization Code

7. AUTHOR(S)

Nora H. Jason

9. PERFORMING ORGANIZATION NAME AND ADDRESS

NATIONAL BUREAU OF STANDARDS

DEPARTMENT OF COMMERCE

WASHINGTON, D.C. 20234

8. Performing Organ. Report No.

10. Project/Task/Work Unit No. 7513678

11. Contract/Grant No.

12. Sponsoring Organization Name and Complete Address (Stroet, City, State, ZIP)

Same as No. 9

13. Type of Report \& Period Corered

Final

14. Sponsoring Agency Code

15. SUPPLEMENTARY NOTES

16. ABSTRACT (A 200-word or less factual summary of most significant information. If document includes a significant bitliography or literature survey, mention it here.)

"Fire Research Publications, 1977" is a supplement to the previous edition:
1969-72 NBSIR 73-246
1973 NBSIR 74-511
NTIS Order No. COM-74-10989
$\$ 3.25$
COM-74-11448
$\$ 3.25$
1974
NBSIR 75-736
COM-75-11018
$\$ 3.25$
1975 NBSIR-76-1120
$\mathrm{PB}-257837$
$\$ 3.50$
1976
NBSIR 77-1277
PB-269965
$\$ 3.50$

Only publications prepared by members of the Center for Fire Research (CFR), by other National Bureau of Standards (NBS) personnel or external laboratories under contract or grant from the CFR are cited. Articles published in NBS house organs also are cited.

17. KEY WORDS (six to twelve entries; alphabetical onder; capitallze anly the firat lotter of the first key word unless o proper name; separated by semicolons)

Bibllographies; bullding fires; carpets; compartment fires; fire detection systems; fire suppression; fire tests; flame research; flammability tests; smoke; smoke detectors; standards; toxicity.

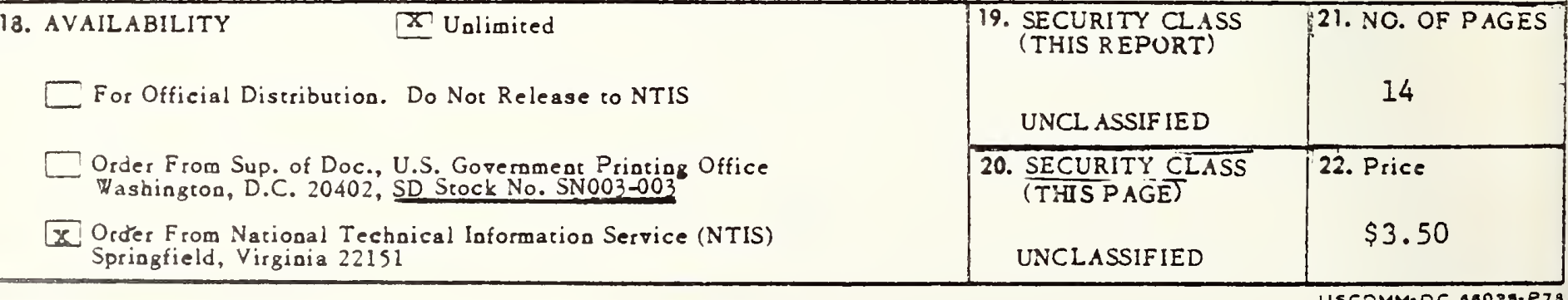



